\title{
Fluorescent Enzyme Immunoassay
}

National Cancer Institute

\section{Source}

National Cancer Institute. Fluorescent Enzyme Immunoassay. NCI Thesaurus. Code C142336.

An assay technique that uses enzymes, which when bound to the substrate transform into a fluorescent product, to detect the presence of a substance, usually an antigen. 